\title{
Diffuse Dermal Angiomatosis: A Clue to the Diagnosis of Atherosclerotic Vascular Disease
}

\author{
Tueboon Sriphojanart Vasanop Vachiramon \\ Division of Dermatology, Faculty of Medicine, Ramathibodi Hospital, Mahidol University, \\ Bangkok, Thailand
}

\section{Key Words}

Atherosclerosis · Diffuse dermal angiomatosis · Reactive angiomatosis

\begin{abstract}
Diffuse dermal angiomatosis (DDA) is a benign, acquired, reactive vascular proliferation. DDA is clinically characterized by painful purpuric plaque with central ulceration. The histopathologic hallmark is diffuse proliferation of endothelial cells that are arranged interstitially between collagen bundles of the reticular dermis. DDA has been reported in association with peripheral atherosclerotic disease, arteriovenous fistula and heavy smoking. We report the case of a 49-year-old Asian male with DDA who presented with a painful stellate-shaped purpuric patch on the right thigh. Histopathologic examination showed proliferation of CD34-positive spindle cells in the dermis. Our patient underwent vascular bypass surgery along with tight control of cardiovascular risk factors, which yielded successful results.
\end{abstract}

(c) 2015 S. Karger AG, Basel

\section{Introduction}

Diffuse dermal angiomatosis (DDA) is a benign, acquired, reactive vascular proliferation; it is a variant of reactive angioendotheliomatosis. DDA is characterized by painful, violaceous, purpuric and occasionally ulcerated plaques mainly on the lower extremities of patients with peripheral vascular atherosclerotic disease.

KARGER 125/s $\quad \begin{aligned} & \text { Vasanop Vachiramon, MD } \\ & \text { Division of Dermatology, Faculty of Medicine } \\ & \text { Ramathibodi Hospital, Mahidol University } \\ & \text { 270 Rama VI Road, Rajthevi, Phayathai, Bangkok } 10400 \text { (Thailand) } \\ & \text { E-Mail vasanop@gmail.com }\end{aligned}$


Sriphojanart and Vachiramon: Diffuse Dermal Angiomatosis: A Clue to the Diagnosis of Atherosclerotic Vascular Disease

\section{Case Report}

A 49-year-old Asian male presented with a painful lesion on right thigh. It had gradually become larger and markedly painful. During the previous 6 months, he had also had intermittent claudication of both legs, the right being worse. His medical history was significant for coronary artery disease, diabetes mellitus, dyslipidemia, hypertension and heavy smoking. Medications included aspirin (325 mg/day), isosorbide dinitrate, glipizide, simvastatin, carvedilol and hydralazine. No other pertinent symptoms were found in systems review. He had no history of previous surgery or trauma on either leg.

Physical examination revealed a solitary, well-defined, stellate-shaped purpuric patch, $10 \times 12 \mathrm{~cm}$, on the right thigh, with a superficial central ulceration covered by a hemorrhagic crust (fig. 1). Femoral, popliteal, posterior tibial and dorsalis pedis pulses were absent on both sides. No gangrene or clinical signs of chronic venous insufficiency were observed. There was no lymphadenopathy. A biopsy specimen was obtained from the edge of the lesion. Histopathology showed interstitial proliferation of spindle cells in association with extravasated red blood cells and sparse perivascular inflammatory cell infiltration in the dermis without intravascular proliferation (fig. 2). These spindle cells were positive for CD31 and CD34 (fig. 3) and negative for HHV-8. Computed tomography angiography showed total occlusion of the right infrarenal aorta extending to the aortic bifurcation, both common iliac arteries and the internal and external iliac arteries (fig. 4). Coagulogram was within normal limits.

The diagnosis was DDA. Our patient underwent right axillo-femoral and left femorofemoral bypass surgery, along with tight control of cardiovascular risk factors, which yielded successful results. The painful lesion rapidly disappeared within 1 week after the operation, leaving postinflammatory hyperpigmentation and a central reticulate scar.

\section{Discussion}

DDA is a benign vascular disorder of the skin, classified in the group of cutaneous reactive angiomatosis [1]. It has been described in association with atherosclerotic peripheral vascular disease [2]. It is hypothesized that ischemia or inflammation generates a local hypoxic stimulus, which results in increased vascular endothelial growth factor, endothelial proliferation and neovascularization. In addition, vascular occlusion caused by atherosclerotic plaques may be a source of emboli to distal cutaneous vessels, where they could induce neoangiogenesis [3].

The clinical presentations of DDA consist of erythematous to violaceous, livedoid patches, often with central ulceration [1]. The lesions may be solitary or multiple and are typically found on the lower extremities in patients with severe atherosclerotic disease. DDA has been reported on the forearm secondary to iatrogenic arteriovenous fistulas in chronic hemodialysis patients and in women with nonhealing, ulcerating lesions on the breast $[3,4]$. In addition, this cutaneous reactive pattern has also been reported in association with a variety of diseases that cause vasculopathy, including calciphylaxis [5, 6], monoclonal gammopathy [7, 8] and cutis marmorata telangiectatica congenita [9]. The differential diagnosis of DDA includes vasculopathy, medium to large vessel vasculitis, acroangiodermatitis and benign or malignant vascular tumor.

Histologically, DDA is characterized by diffuse proliferation of endothelial cells interstitially arranged between collagen bundles within the dermis [1]. Frequently, the proliferating cells may show a spindled morphology, vacuolated cytoplasm and formation of small vascu- 
Sriphojanart and Vachiramon: Diffuse Dermal Angiomatosis: A Clue to the Diagnosis of Atherosclerotic Vascular Disease

lar channels, suggesting neoangiogenesis. Scattered extravasated red blood cells and hemosiderin deposition may be apparent. Atypical mitotic figures are always absent.

Immunohistochemistry shows positivity of endothelial cells for Ulex europaeus agglutinin-1, factor VIII-associated antigen, CD31 and CD34 [3, 5]. The histologic differential diagnosis includes Kaposi sarcoma, well-differentiated angiosarcoma and acroangiodermatitis. However, cytologic atypia, diffuse slit-like lumen formation and the promontory sign along with the inflammatory component are lacking. Acroangiodermatitis, by contrast, exhibits slight endothelial proliferation and formation of new thick-walled vessels in a lobular arrangement in the dermis.

We performed a PubMed search using the term 'diffuse dermal angiomatosis' and found 29 cases in the English language literature, of which 11 were associated with peripheral artery disease (table 1). The characteristic clinical features of the reported patients were reticulated, erythematous to purpuric plaque with central necrotic area. The medial thigh was most frequently reported. In addition, all reported patients had multiple atherosclerotic comorbidities such as hypertension, dyslipidemia, diabetes mellitus, chronic kidney disease and heavy smoking. Most of them had undergone revascularization procedures, and all lesions rapidly healed shortly after the procedures [2, 10-17]. However, one reported patient who received conservative medical therapy, which included oral prednisolone and colchicine, died from severe sepsis.

The management of DDA generally requires improving underlying tissue hypoxia and ischemia. Revascularization, such as vascular surgery for correcting and bypassing the vascular occlusion, is the most efficient method, particularly in cases caused by vaso-occlusive disease, and generally results in complete or near-complete lesion resolution [11]. The treatment also includes strict control of cardiovascular risk factors. Systemic steroids and isotretinoin have been successfully used as well, based on their inhibitory effect on neoangiogenesis [4].

\section{Summary}

DDA is not an uncommon benign vascular condition. It should be considered in a patient who presents with painful, nonhealing purpuric plaque with central ulceration on the upper thigh. Prompt recognition is important as surgical intervention is often curative, thereby limiting the associated morbidity.

\section{Statement of Ethics}

We state that our patient gave informed consent. The research complies with all ethical guidelines for human studies.

\section{Disclosure Statement}

The authors declare that they have no conflict of interest and that they received no funding. 
Sriphojanart and Vachiramon: Diffuse Dermal Angiomatosis: A Clue to the Diagnosis of Atherosclerotic Vascular Disease

\section{References}

1 Rongioletti F, Rebora A: Cutaneous reactive angiomatoses: patterns and classification of reactive vascular proliferation. J Am Acad Dermatol 2003;49:887-896.

-2 Kimyai-Asadi A, Nousari HC, Ketabchi N, Henneberry JM, Costarangos C: Diffuse dermal angiomatosis: a variant of reactive angioendotheliomatosis associated with atherosclerosis. J Am Acad Dermatol 1999;40: 257-259.

-3 Requena L, Fariña MC, Renedo G, Alvarez A, Yus ES, Sangueza OP: Intravascular and diffuse dermal reactive angioendotheliomatosis secondary to iatrogenic arteriovenous fistulas. J Cutan Pathol 1999;26:159-164.

4 McLaughlin ER, Morris R, Weiss SW, Arbiser JL: Diffuse dermal angiomatosis of the breast: response to isotretinoin. J Am Acad Dermatol 2001;45:462-465.

5 Prinz Vavricka BM, Barry C, Victor T, Guitart J: Diffuse dermal angiomatosis associated with calciphylaxis. Am J Dermatopathol 2009;31:653-657.

-6 Steele KT, Sullivan BJ, Wanat KA, Rosenbach M, Elenitsas R: Diffuse dermal angiomatosis associated with calciphylaxis in a patient with end-stage renal disease. J Cutan Pathol 2013;40:829-832.

7 Ferreli C, Atzori L, Pinna AL, Pau M, Aste N, Ricotti C, Rongioletti F: Diffuse dermal angiomatosis: a clinical mimicker of vasculitis associated with calciphylaxis and monoclonal gammopathy. G Ital Dermatol Venereol 2015;150:115-121.

8 Quatresooz P, Fumal I, Willemaers V, Cornil F, Piérard GE: Diffuse dermal angiomatosis: a previously undescribed pattern of immunoglobulin and complement deposits in two cases. Am J Dermatopathol 2006;28:150-154.

-9 Halbesleben JJ, Cleveland MG, Stone MS: Diffuse dermal angiomatosis arising in cutis marmorata telangiectatica congenita. Arch Dermatol 2010;146:1311-1313.

10 Draper BK, Boyd AS: Diffuse dermal angiomatosis. J Cutan Pathol 2006;33:646-648.

11 Morimoto K, Iioka H, Asada H, Kichikawa K, Taniguchi S, Kuwahara M: Diffuse dermal angiomatosis. Eur J Vasc Endovasc Surg 2011;42:381-383.

-12 Krell JM, Sanchez RL, Solomon AR: Diffuse dermal angiomatosis: a variant of reactive cutaneous angioendotheliomatosis. J Cutan Pathol 1994;21:363-370.

-13 Kim S, Elenitsas R, James WD: Diffuse dermal angiomatosis: a variant of reactive angioendotheliomatosis associated with peripheral vascular atherosclerosis. Arch Dermatol 2002;138:456-458.

14 Kirkland CR, Hawayek LH, Mutasim DF: Atherosclerosis-induced diffuse dermal angiomatosis with fatal outcome. Arch Dermatol 2010;146:684-685.

15 Crickx E, Saussine A, Vignon-Pennamen MD, Cordoliani F, Mouly F, Bagot M, Rybojad M: Diffuse dermal angiomatosis associated with severe atherosclerosis: two cases and review of the literature. Clin Exp Dermatol 2015, Epub ahead of print.

$\$ 16$ Bauer J, Maroon M, Rodenhaver T: Diffuse dermal angiomatosis: characterization of a rare and evolving proliferative vascular endothelial process. J Am Acad Dermatol 2007;56(suppl 2):AB81.

17 Walton K, Liggett J: Diffuse dermal angiomatosis: a case report. J Am Acad Dermatol 2012;66(suppl 1):AB49. 


\section{Case Reports in Dermatology}

\begin{tabular}{l|l}
\hline \multicolumn{2}{l}{ Case Rep Dermatol 2015;7:100-106 } \\
\hline DOI: $10.1159 / 000430944$ & $\begin{array}{l}\text { C 2015 S. Karger AG, Basel } \\
\text { www.karger.com/cde }\end{array}$ \\
\hline
\end{tabular}

Sriphojanart and Vachiramon: Diffuse Dermal Angiomatosis: A Clue to the Diagnosis of Atherosclerotic Vascular Disease

Table 1. Reported cases of peripheral artery disease associated with DDA

\begin{tabular}{|c|c|c|c|c|c|c|c|c|c|}
\hline $\begin{array}{l}\text { Reference } \\
\text { (first author), } \\
\text { year }\end{array}$ & $\begin{array}{l}\text { Cases, } \\
\mathrm{n}\end{array}$ & $\begin{array}{l}\text { Age, } \\
\text { years }\end{array}$ & Sex & $\begin{array}{l}\text { Clinical } \\
\text { presentation }\end{array}$ & Location & $\begin{array}{l}\text { Underlying } \\
\text { diseases }\end{array}$ & Angiogram & Treatment & Outcome \\
\hline \multirow[t]{2}{*}{$\begin{array}{l}\text { Krell [12], } \\
1994\end{array}$} & 2 & 47 & $\mathrm{~F}$ & $\begin{array}{l}\text { large ulcer with } \\
\text { erythematous } \\
\text { border }\end{array}$ & $\begin{array}{l}\text { rt. medial } \\
\text { thigh }\end{array}$ & PAD & NA & $\begin{array}{l}\text { rt. axillo-femoral } \\
\text { bypass graft }\end{array}$ & $\begin{array}{l}\text { re-epitheli- } \\
\text { alized ulcer }\end{array}$ \\
\hline & & 63 & $\mathrm{~F}$ & $\begin{array}{l}\text { large painful EP, } \\
\text { central erosions }\end{array}$ & $\begin{array}{l}\text { lt. medial } \\
\text { thigh }\end{array}$ & PAD & NA & $\begin{array}{l}\text { revision of } \\
\text { occluded graft }\end{array}$ & $\begin{array}{l}\text { completely } \\
\text { healed }\end{array}$ \\
\hline $\begin{array}{l}\text { Kimyai-Asadi } \\
{[2], 1999}\end{array}$ & 1 & 57 & $\mathrm{~F}$ & $\begin{array}{l}\text { blanchable, } \\
\text { reticulated, EP } \\
\text { with a 3-cm } \\
\text { purpuric and } \\
\text { necrotic area }\end{array}$ & $\begin{array}{l}\text { lt. upper } \\
\text { medial } \\
\text { thigh }\end{array}$ & $\begin{array}{l}\text { HT, } \\
\text { smoking, } \\
\text { PAD, CKD }\end{array}$ & $\begin{array}{l}\text { complete occlusion } \\
\text { of the lt. renal artery } \\
\text { and the infrarenal } \\
\text { aorta with collateral } \\
\text { flow to the lower } \\
\text { extremities }\end{array}$ & $\begin{array}{l}\text { aortobifemoral } \\
\text { bypass surgery }\end{array}$ & $\begin{array}{l}\text { completely } \\
\text { cleared }\end{array}$ \\
\hline $\begin{array}{l}\text { Kim [13], } \\
2002\end{array}$ & 1 & 58 & $\mathrm{~F}$ & $\begin{array}{l}\text { violaceous } \\
\text { plaque }\end{array}$ & $\begin{array}{l}\text { lt. medial } \\
\text { thigh }\end{array}$ & $\begin{array}{l}\text { HT, DM, } \\
\text { heavy } \\
\text { smoking }\end{array}$ & $\begin{array}{l}\text { bilateral ischemic } \\
\text { disease (Doppler } \\
\text { ultrasound) }\end{array}$ & NA & NA \\
\hline $\begin{array}{l}\text { Draper [10], } \\
2006\end{array}$ & 1 & 53 & M & $\begin{array}{l}\text { violaceous EP } \\
\text { with focal } \\
\text { ulcerations }\end{array}$ & $\begin{array}{l}\text { lt. lateral } \\
\text { leg }\end{array}$ & $\begin{array}{l}\text { PAD, HT, } \\
\text { CAD, COPD }\end{array}$ & $\begin{array}{l}80 \% \text { stenosis of } \\
\text { the lt. external } \\
\text { iliac artery }\end{array}$ & $\begin{array}{l}\text { revascularization } \\
\text { procedure }\end{array}$ & $\begin{array}{l}\text { complete } \\
\text { healing }\end{array}$ \\
\hline $\begin{array}{l}\text { Bauer [16], } \\
2007\end{array}$ & 1 & 57 & $\mathrm{~F}$ & $\begin{array}{l}\text { adherent } \\
6 \text {-mm eschar, } \\
\text { surrounding } \\
\text { erythema }\end{array}$ & $\begin{array}{l}\text { rt. medial } \\
\text { thigh }\end{array}$ & $\begin{array}{l}\text { HT, protein } \\
\text { C deficiency, } \\
\text { anti-thrombin } \\
\text { III deficiency, } \\
\text { CKD, AF }\end{array}$ & NA & NA & NA \\
\hline $\begin{array}{l}\text { Kirkland } \\
{[14]} \\
2010\end{array}$ & 1 & 58 & $\mathrm{~F}$ & $\begin{array}{l}\text { violaceous, } \\
\text { indurated and } \\
\text { reticulated } \\
\text { patches with } \\
\text { central necrosis }\end{array}$ & $\begin{array}{l}\text { lt. inner thigh, } \\
\text { lt. buttock } \\
\text { and lt. lower } \\
\text { quadrant of } \\
\text { the abdomen }\end{array}$ & $\begin{array}{l}\text { heavy smok- } \\
\text { ing, HT, PAD } \\
\text { treated with } \\
\text { bilateral } \\
\text { iliac stents }\end{array}$ & $\begin{array}{l}\text { decreased blood } \\
\text { flow distal to lt. iliac } \\
\text { stent (Duplex scan) }\end{array}$ & $\begin{array}{l}\text { re-stent the lt. } \\
\text { common iliac } \\
\text { artery }\end{array}$ & failed \\
\hline $\begin{array}{l}\text { Morimoto } \\
{[11], 2011}\end{array}$ & 1 & 65 & M & $\begin{array}{l}\text { painful, ery- } \\
\text { thematous lesion } \\
\text { with central } \\
\text { necrosis }\end{array}$ & $\begin{array}{l}\text { rt. lower } \\
\text { leg }\end{array}$ & $\begin{array}{l}\text { HT and } \\
\text { heavy } \\
\text { smoking }\end{array}$ & $\begin{array}{l}\text { occlusion of the } \\
\text { rt. superficial } \\
\text { femoral artery }\end{array}$ & $\begin{array}{l}\text { oral prednisolone, } \\
\text { catheter recanali- } \\
\text { zation, balloon } \\
\text { angioplasty }\end{array}$ & improved \\
\hline $\begin{array}{l}\text { Walton [17], } \\
2012\end{array}$ & 1 & 58 & M & $\begin{array}{l}\text { nonhealing, } \\
\text { painful, ulcerating } \\
\text { plaques }\end{array}$ & $\begin{array}{l}\text { bilateral } \\
\text { thighs and } \\
\text { buttocks }\end{array}$ & - & $\begin{array}{l}\text { severe arterial } \\
\text { disease }\end{array}$ & $\begin{array}{l}\text { stent revascular- } \\
\text { ization }\end{array}$ & improved \\
\hline \multirow[t]{2}{*}{$\begin{array}{l}\text { Crickx [15], } \\
2015\end{array}$} & 2 & 71 & $\mathrm{~F}$ & $\begin{array}{l}\text { violaceous, } \\
\text { ill-defined, } \\
\text { maculonodular } \\
\text { eruption with } \\
\text { livedoid plaques, } \\
\text { painful necrotic } \\
\text { ulcerations }\end{array}$ & $\begin{array}{l}\text { trunk and } \\
\text { extremities }\end{array}$ & $\begin{array}{l}\mathrm{DM}, \mathrm{HT}, \\
\mathrm{CKD} \text { and } \mathrm{AF}\end{array}$ & $\begin{array}{l}\text { atherosclerotic } \\
\text { infiltration of the } \\
\text { aorta and its } \\
\text { branches without } \\
\text { occlusion }\end{array}$ & $\begin{array}{l}\text { colchicine, oral } \\
\text { prednisolone } \\
\text { and oxygen }\end{array}$ & failed \\
\hline & & 81 & M & $\begin{array}{l}\text { bluish EP with } \\
\text { telangiectasia }\end{array}$ & rt. shoulder & $\begin{array}{l}\text { heavy smok- } \\
\text { ing, severe } \\
\text { PAD, HT, } \\
\text { dyslipidemia }\end{array}$ & NA & NA & NA \\
\hline
\end{tabular}

$\mathrm{AF}=$ Atrial fibrillation; $\mathrm{CAD}=$ coronary artery disease; $\mathrm{CKD}=$ chronic kidney disease $\mathrm{COPD}=$ chronic obstructive pulmonary disease; $\mathrm{DM}=$ diabetes mellitus; $\mathrm{EP}$ = erythematous plaque; $\mathrm{HT}$ = hypertension; lt. = left; NA = not available; $\mathrm{PAD}$ = peripheral artery disease; rt. = right. 


\section{Case Reports in Dermatology}

Sriphojanart and Vachiramon: Diffuse Dermal Angiomatosis: A Clue to the Diagnosis of Atherosclerotic Vascular Disease

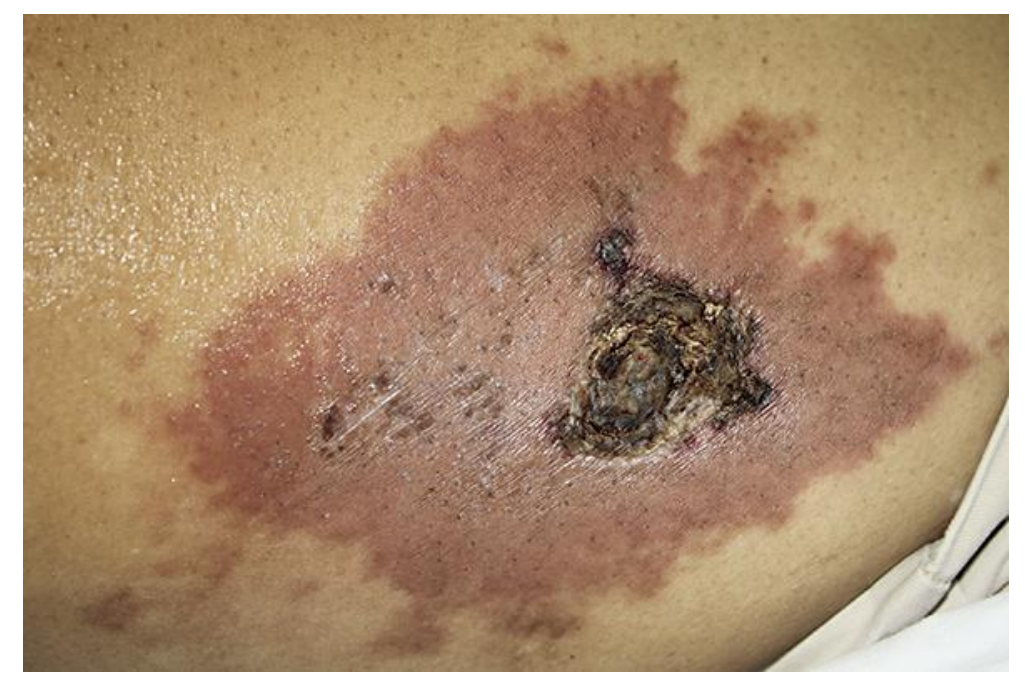

Fig. 1. Serrated purpuric patch on the right thigh, with a superficial central ulceration covered by a hemorrhagic crust.
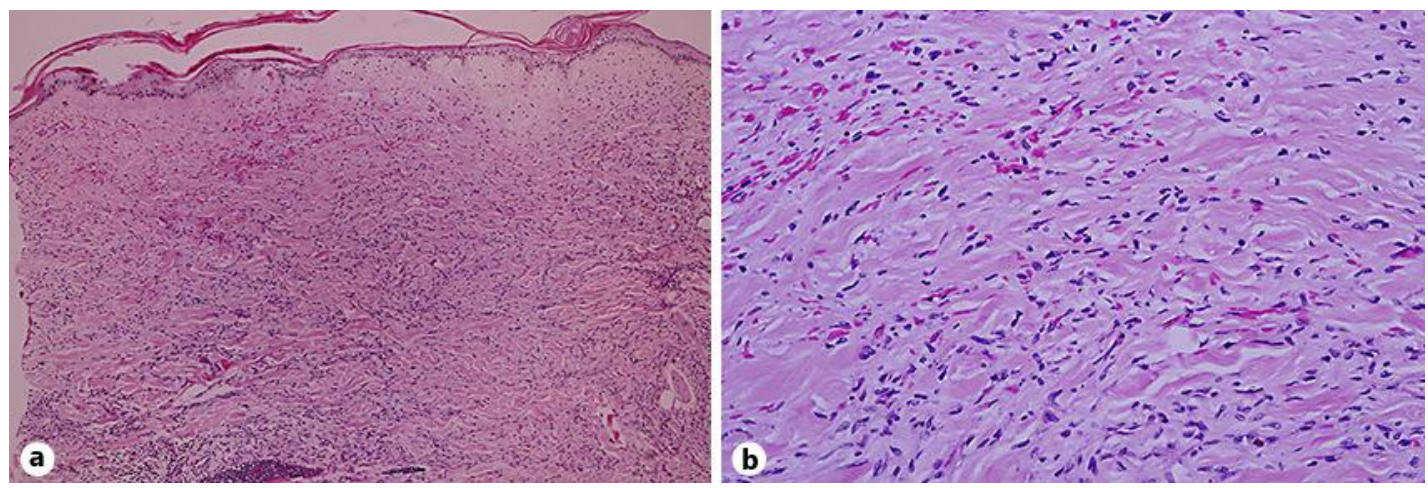

Fig. 2. Interstitial proliferation of spindle cells in association with extravasated red blood cells and sparse perivascular inflammatory cell infiltration in the dermis. Hematoxylin and eosin, original magnification $\times 100(a), \times 400(b)$. 
Sriphojanart and Vachiramon: Diffuse Dermal Angiomatosis: A Clue to the Diagnosis of Atherosclerotic Vascular Disease

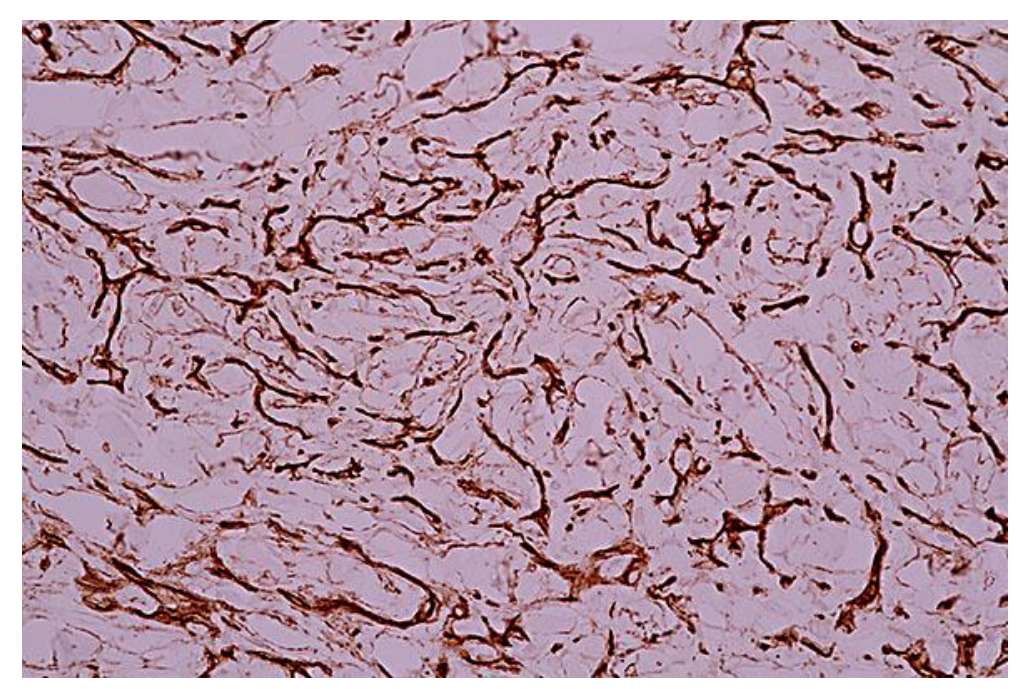

Fig. 3. Spindle cells were positive for CD34, suggesting vascular proliferation. CD34, original magnification $\times 400$.
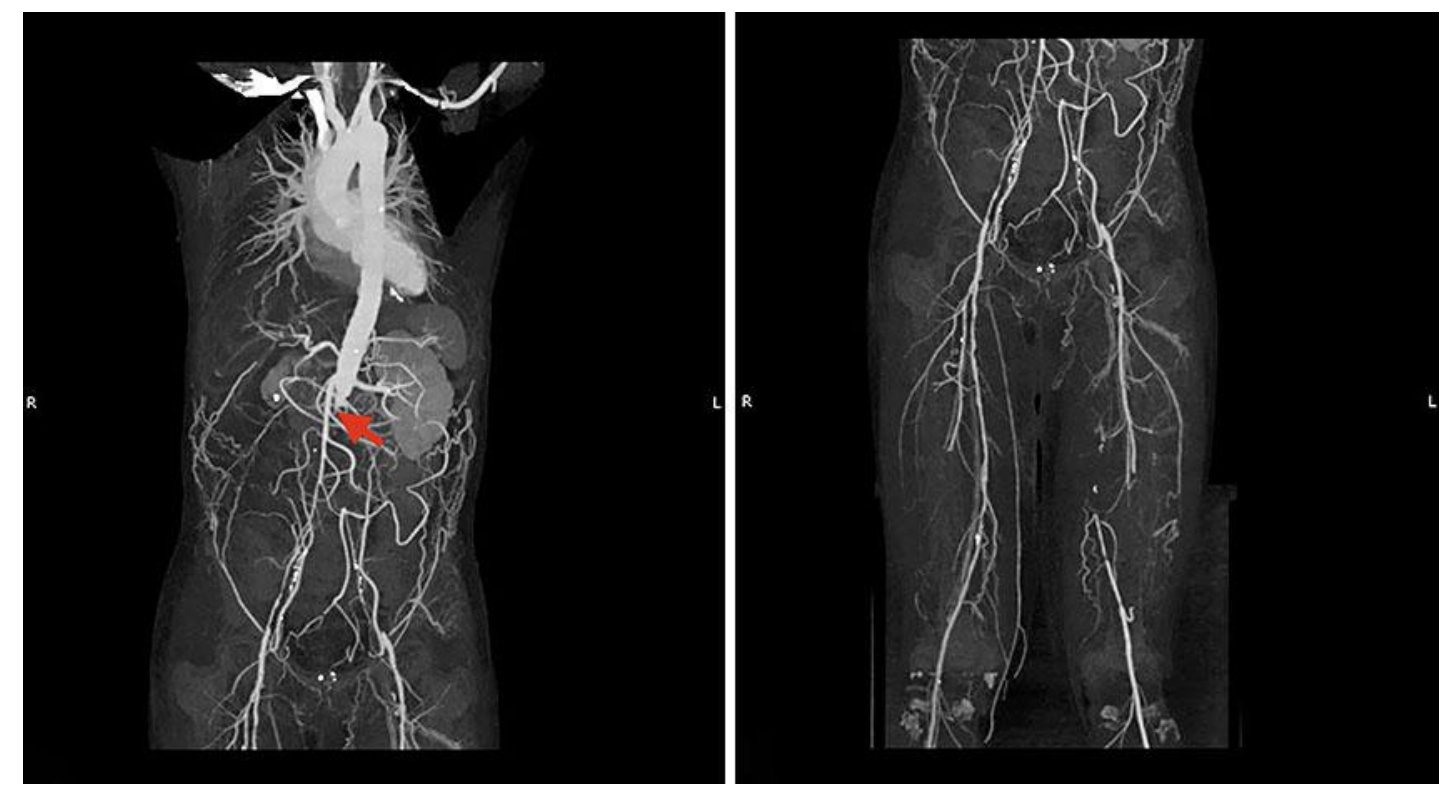

Fig. 4. Computed tomography angiography showing total occlusion of the right infrarenal aorta extending to the aortic bifurcation (arrow), both common iliac arteries and the internal and external iliac arteries. 